\section{Synthesis of}

Heterocycles

\section{Key words}

asymmetric organocatalysis

$\gamma$-lactams

$\delta$-lactams

$\delta$-lactones

radical reaction
S. VEllalATH, K. N. VAN, D. ROMO* (TEXAS A\&M UNIVERSity, COLlEGE STATION, USA) Direct Catalytic Asymmetric Synthesis of N-Heterocycles from Commodity Acid Chlorides by Employing $\alpha, \beta$-Unsaturated Acylammonium Salts Angew. Chem. Int. Ed. 2013, DOI: 10.1002/anie.201306050.

\title{
Asymmetric Organocatalytic Synthesis of Lactams and Lactones
}

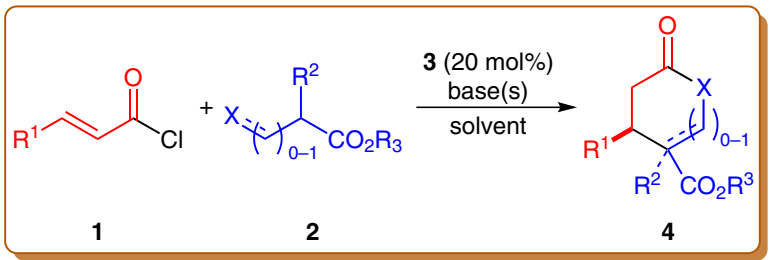

Selected examples: pyrrolidinones and piperidinones

\section{catalyst: $\mathbf{3 b}$}

bases:

LiHMDS (1 equiv)

DBU (1 equiv)

solvent: THF

conditions: $-30^{\circ} \mathrm{C}, 18 \mathrm{~h}$

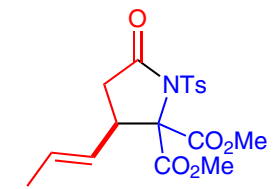

$80 \%$ yield, $93 \%$ ee used 2 equiv of $1,-10^{\circ} \mathrm{C}$

Selected examples: enol $\delta$-lactones

catalyst: $\mathbf{3 a}, \mathbf{3 c}$

bases:

LiHMDS (1 equiv)

DBU (1 equiv)

solvent: THF

conditions: $-30{ }^{\circ} \mathrm{C}, 18 \mathrm{~h}$

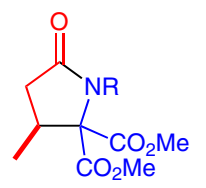

$\mathrm{R}=\mathrm{Bz} 78 \%$ yield, $86 \%$ ee (gram scale)

Ts $73 \%$ yield, $93 \%$ ee

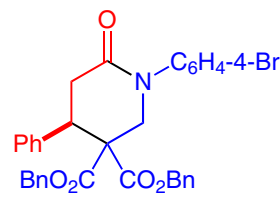

$40 \%$ yield, $93 \%$ ee used 2 equiv of $1,-15^{\circ} \mathrm{C}$

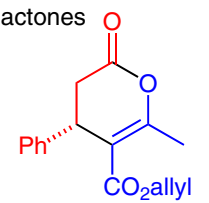

$52 \%$ yield, $90 \%$ ee catalyst $3 c$

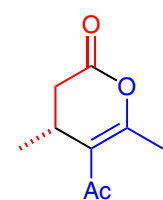

$48 \%$ yield, $89 \%$ ee catalyst $3 \mathrm{c}, 0^{\circ} \mathrm{C}$<smiles>C=CC1CC2CCN1CC2[C@H](OC)c1ccnc2ccc(OC)cc12</smiles><smiles>C=CC1CC2CCN1CC2[C@H](OC)c1ccnc2ccc(OC)cc12</smiles>

$3 a$ $\mathbf{3 c}=(\mathrm{DHQ})_{2} \mathrm{PHAL}$

3b

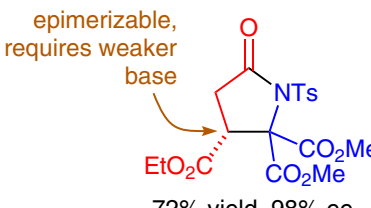

catalyst: $3 c$, bases: LiHMDS and DIPEA

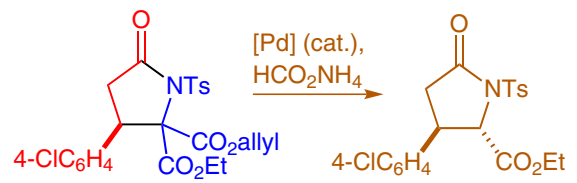

$74 \%$ yield,$-15{ }^{\circ} \mathrm{C} \quad 71 \%$ yield, $99 \%$ ee, $\mathrm{dr}=19: 1$ gram-scale synthesis of drug intermediate

Example: 3,4-dihydro-2-pyridinones

\section{catalyst $\mathbf{3 b}$}

base: DIPEA ( 3 equiv) additive: $\mathrm{LiCl}$ (1 equiv) $4 \AA$ MS

solvent: $\mathrm{PhMe}$

conditions: $23^{\circ} \mathrm{C}, 20 \mathrm{~h}$
Significance: The reported method for the synthesis of lactams and lactones 4 employs quinineand quinidine-derived catalysts 3 to activate $\alpha, \beta$ unsaturated acid chlorides $\mathbf{1}$ toward reaction with bisnucleophiles 2 . A variety of heterocycles relevant to medicinal and natural product chemistry were obtained, including 2-pyrrolidinones, 2-piperidinones, enol $\delta$-valerolactones, and 3,4-dihydro-2-pyridinones. The yields are modest to good and enantioselectivity is good to excellent. The method was demonstrated to provide two intermediates for drug synthesis (one on a gram scale).

SYNFACTS Contributors: Victor Snieckus, Benjamin N. Rocke (Pfizer) Synfacts 2014, 10(1), 0022 Published online: 13.12.2013 Dol: 10.1055/s-0033-1340427; Reg-No.: V15813SF
Comment: For success of the reported method, significant tuning of the reaction conditions to the substrate, including the use of excess reactant; the choice of base, catalyst, and temperature; and the use of additives, is required. Catalyst $\mathbf{3} \mathbf{b}$ affords products of opposite configuration to those obtained using $\mathbf{3 a}$ or $\mathbf{3 c}$; although, in our opinion, the publication relies too heavily on assumptions in drawing this conclusion. In the synthesis of piperidinones, a retro-aza Michael side reaction results in low yields of the desired product. Interestingly, Michael addition, not acylation, appears to be the first mechanistic step, a fact essential to explaining the enantioselectivity. 